\title{
LINDY TRINKAUS ZAGZEBSKI TEORIA AUTORYTETU POZNAWCZEGO. O POTRZEBIE UFANIA INNYM
}

\begin{abstract}
Streszczenie. W niniejszym artykule autor analizuje teorię autorytetu przedstawioną przez Trinkaus Zagzebski. Teoria ta podkreśla rolę zaufania w uzasadnianiu zdań, m.in. wskazując na ograniczenia stanowiska egoizmu poznawczego, dla którego ideałem jest sytuacja, w której podmiot, uzasadniając swe przekonania, polega tylko na własnych zdolnościach poznawczych. Trinkaus Zagzebski broni uniwersalizmu poznawczego, wg którego już sam fakt, że osoba x, głosi że p, jest prima facie racją za p. W tekście autor wskazuje na słabe punkty uniwersalizmu i konkluduje, że albo uznamy to stanowisko z jego konsekwentnym odrzuceniem tezy o równości podmiotów poznających, albo też mimo wszystko opowiemy się za egoizmem poznawczym. Autor uznaje przy tym, że amerykańska filozofka daje nam wskazówki, jak ulepszyć owo stanowisko, by nie prowadziło ono do twierdzeń sprzecznych z intuicją.
\end{abstract}

Słowa kluczowe: autorytet poznawczy, egoizm poznawczy, uniwersalizm poznawczy, poznawcze zaufanie innym, fundamentalizm epistemologiczny, racje teoretyczne i przemyślane, poznawcza sumienność

1. Wstęp. 2. Egoizm poznawczy. 3. Uniwersalizm poznawczy. 4. Racje teoretyczne i przemyślane.

5. Umiarkowany i skrajny egoizm poznawczy. 6. Podsumowanie.

\section{WSTĘP}

Argument $\mathrm{z}$ autorytetu jest uważany w epistemologii za najsłabszą możliwą rację, jaką można wysunąć na rzecz bronionego poglądu. Filozofia scholastyczna ukuła formuły typu: Auctoritas est debilissimum argumentum czy też Contra factum non valet auctoritas, zaś w nowożytności John Locke pisał: „Taka jest już bowiem natura ludzkiego umysłu, że żadną przemocą z zewnątrz zniewolić się nie da"1. Odrzucenie autorytetu zaczęto w tym czasie wiązać z koniecznością

1 J. Locke, List o tolerancji, tłum. z ang. L. Joachimowicz, Warszawa 1963, 9. 
zachowania ideału autonomii w procesie poznawczym, a pewnego rodzaju niekwestionowanym dogmatem stało się przekonanie, że fakt, iż dana osoba głosi, że p, nie jest żadną racją za prawdziwością p. W niniejszym artykule postaram się odpowiedzieć na pytanie: czy możliwa jest rehabilitacja autorytetu w epistemologii? Czy racjonalnym jest uznawanie pewnych twierdzeń za prawdziwe tylko dlatego, że ktoś inny je za takie uznaje? Czy fakt, że dana osoba uważa dane twierdzenie za prawdziwe, jest prima facie racją za tym twierdzeniem? Powodem, dla którego zajmuję się odpowiedzią na tego rodzaju pytania, jest spostrzeżenie, że analiza obrony i krytyki autorytetu w epistemologii pozwala na wyciągnięcie ciekawych wniosków na temat natury naszej racjonalności oraz podmiotu poznającego. Wnioski te mogą być ukryte, kiedy milcząco przyjmujemy wyżej wspomniany dogmat epistemologii.

Podobne kwestie podjęła ostatnio w swej pracy amerykańska filozofka Linda Trinkaus Zagzebski ${ }^{2}$. W swym tekście będę głównie analizował jej propozycję epistemologii autorytetu oraz spróbuję wyjść poza ograniczenia tej koncepcji. Moim głównym zarzutem wobec Trinkaus Zagrzebski jest to, że mimo deklaracji nie udało jej się przekroczyć zwalczanego przez nią stanowiska egoizmu poznawczego.

\section{EGOIZM POZNAWCZY}

Czy fakt, że dana osoba głosi, że p, jest prima facie racją za p? Odpowiedź negatywna na to pytanie charakteryzuje stanowisko egoizmu poznawczego. Wydaje się, że jest ono powszechnie przyjmowane we współczesnej filozofii. Po Locke’u przejęliśmy pogląd, że akceptacja przez jakąś osobę danego sądu nie powinna mieć żadnego znaczenia

2 L. Trinkaus Zagzebski, Epistemic Authority. A Theory of Trust, Authority and Autonomy in Belief, Oxford 2012. W literaturze filozoficznej kwestia autorytetu nie jest podejmowana zbyt często. Wyjątkiem, obok ww. pracy, są rozważania J. Bocheńskiego zawarte w jego Logice religii (zob. J. I. M. Bocheński, Logika religii, tłum. z ang. S. Magala, Warszawa 1990). 
dla własnej decyzji o akceptacji lub odrzuceniu tegoż sądu. Osoba, która po prostu przejmuje opinie innych, nawet jeśli nie jest uległa czy też niesamodzielna w myśleniu, nie wydaje się nam osobą racjonalną.

Według Trinkaus Zagzebski, egoizm poznawczy jest wynikiem akceptacji dwóch innych poglądów. Oba uznaje za fałszywe:

1. fundamentalizm epistemologiczny - stanowisko to Ernest Sosa ilustrował obrazem, zgodnie z którym ludzka wiedza przypomina piramidę, której górne piętra reprezentują przekonania, których uzasadnieniem są inne przekonania. Przekonania stanowiące fundament, tzw. przekonania bazowe, nie są już uzasadniane za pomocą innych przekonań, lecz ich prawdziwość jest oczywista lub nie do podważenia ${ }^{3}$.

2. ideał autonomii - według tego przekonania, ludzka racjonalność przejawia się przede wszystkim w poleganiu na własnych zdolnościach poznawczych w dochodzeniu do prawdy; zdobywaniu wiedzy tylko własnymi środkami ${ }^{4}$. Zwolennik ideału autonomii uznaje co prawda, że chcąc mieć prawdziwe przekonania, musi korzystać z wiedzy eksperckiej innych, ale ten stan rzeczy świadczy, według niego, o ułomności podmiotu ludzkiego; jest oznaką intelektualnej słabości. Innymi słowy, choć uznaje on konieczność sięgania do wiedzy „z drugiej ręki”, to uważa ją za wiedzę gorszą, do której nie trzeba byłoby się uciekać, gdybyśmy byli w stanie sami uzasadniać wszystkie swe przekonania ${ }^{5}$.

3 Najsłynniejszym zwolennikiem fundamentalizmu epistemologicznego był Kartezjusz. Zob. M. Blaauw, D. Pritchard, Epistemology A-Z, New York 2005, 63-64. Współcześnie jego reprezentantem jest np. Roderick M. Chisholm, który pisze m.in.: „Obecna teoria poznania jest słusznie nazwana fundamentalistyczną, ponieważ do źródeł epistemologicznego uzasadniania zalicza ujęcia bazowe". R. M. Chisholm, Teoria poznania, tłum.

R. Ziemińska, Lublin 1994, 163.

4 L. Trinkaus Zagzebski, Epistemic Authority, dz. cyt., 9.

5 ,Knowledge from trust in testimony is knowledge at second hand, and as such my epistemic position vis-à-vis what I know is in at least one respect inferior to when I know at first hand". E. Fricker, Testimony and Epistemic Autonomy, w: The Epistemology of 
Ad 1. William Alston zwracał uwagę (a Trinkaus Zagzebski przejęła jego punkt widzenia w tej kwestii), że nie sposób ugruntować wiary w wiarygodność percepcji czy też pamięci inaczej niż używając odpowiednio samej percepcji lub pamięci. Innymi słowy, wbrew opinii zwolenników fundamentalizmu epistemologicznego, błędne koło jest nieuniknione w ustalaniu wiarygodności podstawowych źródeł sądów. Jedynym sposobem uniknięcia tego błędnego koła jest, zdaniem Alstona, zaufanie, że nasza percepcja czy też pamięć funkcjonują prawidłowo. Zaufanie to jest w większym stopniu przejawem racjonalności niż uporczywe trwanie przy zasadzie odrzucania jakichkolwiek sposobów formowania sądów, dopóki nie zostały one dostatecznie uzasadnione jako wiarygodne $e^{6}$. Konsekwentnie, na bazie tych przekonań Alstona, tacy autorzy jak Foley czy Fricker argumentowali za racjonalnością postępowania kogoś, kto wiedzę zdobywa w oparciu o zaufanie w zdolności poznawcze innych osób. Tym, co różni stanowisko Trinkaus Zagzebski od tego zajmowanego przez Foley'a, jest przekonanie, że wiedza, którą zdobywamy dzięki zaufaniu innym, nie jest wiedzą gorszego rodzaju? $Z$ kolei Zagzebski nie zgadza się z Fricker, gdy ta głosi, że zaufanie innym jest wyłącznie efektem filozoficznej argumentacji, chcącej uniknąć meandrów sceptycyzmu (według Zagzebski jest ono czymś naturalnym dla podmiotów poznających, gdyż opiera się na naturalnym dążeniu do prawdy ${ }^{8}$ ).

Ad 2. Trinkaus Zagzebski chce utrzymać ideał autonomii, ale przy innym jego rozumieniu: takim, w którym racjonalność człowieka będzie charakteryzowana przede wszystkim przez zdolność

Testimony, red. J. Lakey, R. Sosa, Oxford 2006, 240. Por. też R. Foley, Intellectual Trust in Oneself and Others, Cambridge 2001.

6 W. P. Alston, Beyond Justification: Dimensions of Epistemic Evaluation, Ithaca 2005, 218.

7 L. Trinkaus Zagzebski, Epistemic Self-Trust and the Consensus Gentium Argument, w: Evidence and Religious Belief, red. K. J. Clark, R. J. Vanarragon, Oxford 2011, 25.

8 „I will argue that the natural desire for truth makes epistemic self-trust a requirement, and consistent epistemic self-trust commits us to epistemic trust in others”. Tamże, 22. 
do formułowania sądów prawdziwych (czy też dokładniej, przez zdolność do formułowania sądów, które są w stanie przetrwać jak najdłużej sumienną autorefleksję). Jej rozumienie autonomii zakłada więc uznanie autorytetów epistemicznych, gdyż zaufanie im może niejednokrotnie okazywać się lepszym sposobem na dochodzenie do prawdy, niż odkrywanie jej na własną rękę. Przeciw ideałowi autonomii w jego obecnym rozumieniu autorka wysuwa swój kontrargument:

1. Zaufanie w swoje zdolności poznawcze jest niezbędnym elementem dochodzenia do prawdy (np. zaufanie do percepcji, zaufanie, że istnieje związek między racjami za p a wartością logiczną $p$, itd.).

2. Nie ma znaczących różnic między funkcjonowaniem własnych zdolności poznawczych a funkcjonowaniem zdolności poznawczych innych ludzi. Oczywiście, autorka nie przeczy, że ludzie różnią się pod względem zdolności intelektualnych. Zwraca ona po prostu uwagę na fakt, że ideał autonomii w nieuzasadniony sposób przyznaje perspektywie pierwszoosobowej przewagę w kwestii dochodzenia do prawdy9.

$\mathrm{Z}$ dwóch wyżej wymienionych przesłanek wynika wniosek:

3. Powinienem ufać w zdolności poznawcze innych osób, szczególnie jeśli odkrywam, że posiadają oni cechy, które, gdy ja je posiadam, sprawiają, że tym bardziej ufam swoim zdolnościom poznawczym. Cechy te Trinkaus Zagzebski ogólnie nazywa sumiennością poznawczą (epistemic conscientiousness). Nie ma powodu, według niej, by wyniki procesów poznawczych innych osób wykluczać jako racje we własnym poszukiwaniu prawdy, szczególnie, gdy dostrzegam w nich sumienność ${ }^{10}$.

Według Zagzebski, poznawczemu egoiście pozostaje podważyć jedną z przesłanek kontrargumentu, tzn.

9 L. Trinkaus Zagzebski, Epistemic Authority, dz. cyt., 55-56.

10 Tamże, 57. 
A. Albo musi on przyznać, że zdolność do formułowania sądów prawdziwych wcale nie jest najważniejszym przejawem racjonalności (może np. twierdzić, że jest nim zdolność do samodzielnego poszukiwania prawdy).

B. Albo musi przyznać, że podmioty poznawcze nie są zasadniczo równe, że ma on wyróżnioną pozycję, jeśli chodzi o zdolność dochodzenia do prawdy.

Według Zagzebski, obie strategie są skuteczną odpowiedzią na jej zarzuty. Z drugiej strony nie spodziewa się ona, by ktokolwiek chciał utrzymywać wyżej wymienione poglądy ${ }^{11}$. Według niej, jej ujęcie racjonalności jest bardziej intuicyjne, zaś twierdzenie, że podmioty poznawcze nie są zasadniczo równe, jest sprzeczne $z$ ideałem równości, czyli ideałem równie drogim dla nowożytności, jak ideał autonomii.

Ważnym wnioskiem wynikającym ze scharakteryzowania przez Trinkaus Zagzebski stanowiska egoizmu poznawczego jest spostrzeżenie, że utrzymywanie go prowadzi do sprzecznej z naszymi intuicjami konsekwencji. Otóż, jeśli zgodnie z tym, co głosi egoizm poznawczy, uznam, że wiedzą, a więc prawdziwym sądem uzasadnionym, jest tylko ten sąd, którego prawdziwość uzasadniłem samodzielnie, to nie mam prawa powiedzieć, że np. wiem, że konsekwencją ogólnej teorii względności jest dynamizm przestrzeni fizycznej. Cała bowiem moja wiedza w tym zakresie pochodzi ze świadectwa ekspertów, a więc jest wiedzą z drugiej ręki. Brak mi odpowiedniego wykształcenia matematycznego i przyrodniczego, by samodzielnie sprawdzić, jakie są konsekwencje równań ogólnej teorii względności dla naszego pojmowania fizycznej przestrzeni. Czy rzeczywiście jednak nie wiem, że przestrzeń wszechświata jest dynamiczna, a co więcej, czy rzeczywiście jest czymś irracjonalnym i przeczącym mojej autonomii czerpanie swej wiedzy w tym zakresie $z$ wypowiedzi astrofizyków? Znane są też debaty na temat

11 Tamże, 60. 
realności i powodów zmian klimatycznych. Często przywołuje się w tym kontekście badanie Johna Cooka i Dany Nuticelli oraz ich współpracowników z 2013 roku, w którym przeanalizowano 11944 abstraktów prac o tematyce klimatycznej, a z którego wynikało, że 97\% analizowanych tekstów opowiadało się za realnością zmian klimatycznych i obarczało odpowiedzialnością za nie działalność człowieka $^{12}$. Wyobraźmy sobie osobę, która nie zna się na klimatologii i nie jest w stanie ocenić zebranych dowodów, ale zapoznała się z wyżej wspomnianym badaniem i na jego podstawie wyrobiła sobie opinię, że za zmiany klimatu odpowiada człowiek. Czy rzeczywiście to przekonanie będzie irracjonalne, bądź będzie świadczyło o uległości, niesamodzielności czy też podatności na propagandę $\mathrm{u}$ danej osoby?

\section{UNIWERSALIZM POZNAWCZY}

Krytyka egoizmu poznawczego prowadzi Trinkaus Zagzebski do sformułowania własnego stanowiska, czyli uniwersalizmu poznawczego. Zwolennik tego punktu widzenia twierdzi, że fakt, że dana osoba głosi, że p, jest prima facie racją za $\mathrm{p}^{13}$.

Oczywiście, fakt głoszenia przez kogoś danego poglądu nie jest dla uniwersalisty poznawczego racją przesądzającą za tym poglądem. Uniwersalizm poznawczy nie wyklucza sytuacji, w której, mimo że ktoś, kogo uznaję za autorytet poznawczy w danej dziedzinie, twierdzi, że p lub mimo że twierdzenie p jest powszechnie akceptowane w mojej społeczności, to po rozważeniu wszystkich dostępnych mi racji, stwierdzam, że nie-p. $Z$ drugiej strony, stanowisko uniwersalizmu poznawczego nie jest zupełnie neutralne. Wynika z niego choćby

12 J. Cook, D. Nuticelli, Quantifying the Consensus on Anthropogenic Global Warming in the Scientific Literature, Environmental Research Letters, 8(2013)2, doi: 10.1088/17489326/8/2/024024 doi:10.1088/1748-9326/8/2/024024

13 L. Trinkaus Zagzebski, Epistemic Authority, dz. cyt., 58. 
to, że w sytuacji, w której nie dysponowałbym żadnymi racjami za p, ani żadnymi racjami za nie-p, jeśli zarówno sąd p, jak i sąd nie-p byłyby spójne $z$ innymi uznawanymi przeze mnie sądami, a przypadkowo spotkana nieznana mi wcześniej osoba (co jest istotne o tyle, że w takiej sytuacji nie byłbym w stanie stwierdzić, czy jest ona godna zaufania w kwestii wygłaszanych przez siebie sądów) twierdziłaby, że p, to powinienem przychylić się do twierdzenia, że p. Racja odnosząca się do faktu, że po prostu ktoś głosi, że p, jest bardzo słaba. Niemniej uniwersalista poznawczy uznaje ją za rację, gdyż zaufanie innym jest, według niego, czymś uprzednim wobec jakiejkolwiek refleksji ${ }^{14}$. W omawianej sytuacji, kiedy nie mam żadnych racji za nie-p, ale dysponuję jedną, słabą racją za p, powinienem przychylić się do sądu, że p. Egoista poznawczy w tej samej sytuacji nadal może zachować agnostycyzm. Dla niego fakt głoszenia przez przypadkowo spotkaną osobę jakiegoś poglądu nie jest żadną racją za p. Nadal więc znajduje się w sytuacji, w której, jego zdaniem, zarówno za p, jak i za nie-p nie stoją żadne racje.

Co więcej, wyobraźmy sobie, że uniwersalista poznawczy arbitralnie stwierdził, że nie-p. Fakt, że arbitralnie postanowił wierzyć, że nie-p nie jest dla niego racją za nie-p. Jeśli znów dojdzie do przypadkowego spotkania $z$ nieznaną mu wcześniej osobą, która będzie twierdzić, że p, to powinien on zmienić zdanie. Nie dysponuje on bowiem żadną racją za nie-p, a odkąd usłyszał, że jakaś inna osoba, głosi, że p, to jako uniwersalista poznawczy dysponuje prima facie racją za p. Jest to jednak wniosek o tyle dziwny, że postanowienie, że od dziś będzie się twierdzić, że nie-p, wydaje się być równie bezzasadne i irracjonalne, co decyzja, że będzie się głosić takie same poglądy, jak pierwsza przypadkowo napotkana osoba. Wydaje się

14 „Before we reflect upon the justification of our beliefs or the reliability of our faculties, we already trust ourselves and our environment, including other people. Trust is the condition of the pre-reflective self." Tenże, Epistemic Self-Trust and the Consensus Gentium Argument, art. cyt., 25. 
więc, że podany przeze mnie przykład wskazuje na trudny do zaakceptowania wniosek wynikający ze stanowiska uniwersalizmu poznawczego. Analiza wyżej wspomnianej sytuacji stawia egoistę poznawczego w lepszej sytuacji, gdyż potrafi on na gruncie swojej teorii epistemologicznej pokazać, że w omawianym przykładzie nie dysponujemy żadnymi racjami na rzecz p lub nie-p, niezależnie od tego, co głoszą przypadkowo spotykane osoby.

Sygnalizowany przeze mnie problem Trinkaus Zagzebski formułuje w następującej postaci: o ile fakt, że osoba x uważa, że p jest dla mnie prima facie racją za p, to fakt, że ja uważam, że p nie jest dla mnie dodatkową racją za $\mathrm{p}^{15}$. Poznawczy uniwersalizm wydaje się przeczyć zasadzie równości podmiotów w równym stopniu, co poznawczy egoizm, z tym że, o ile poznawczy egoizm wynosił mnie ponad inne podmioty poznające, to poznawczy uniwersalizm ustawia mnie w pozycji gorszej od innych, jeśli chodzi o możliwości dochodzenia do prawdy. Ukazuje mnie jako niewspółmiernego innym podmiotom, z góry niejako każe się podporządkować poglądom innych ludzi.

\section{RACJE TEORETYCZNE I PRZEMYŚLANE}

Wspomniane konsekwencje zdają się wynikać z tez artykułu Trinkaus Zagzebski Epistemic Self-Trust and the Consensus Gentium Argument. By ich uniknąć, wprowadziła ona w swej późniejszej o rok książce Epistemic Authority podzial na:

1. racje teoretyczne (theoretical reasons) - to fakty dostępne $\mathrm{z}$ trzecioosobowej perspektywy;

2. racje przemyślane (deliberative reasons) - to racje dostępne z pierwszoosobowej, subiektywnej perspektywy, np. emocje $\mathrm{e}^{16}$.

15 Tenże, Epistemic Authority, dz. cyt., 58.

16 Tamże, 63-64. 
Stosując ten podział, można powiedzieć, że fakt, że osoba x uważa, że p, nie jest racją teoretyczną za p, lecz racją przemyślaną za p (opiera się bowiem na zaufaniu do $x$, które to zaufanie jest rodzajem emocji). $Z$ tego podziału wynika równie $\dot{z}, i \dot{z}$ fakt, że uważam, że p, nie jest racją teoretyczną za $\mathrm{p}$, lecz racją przemyślaną za p (opiera się bowiem na zaufaniu do moich zdolności poznawczych).

Czy podział na racje teoretyczne i przemyślane rzeczywiście rozwiązuje sygnalizowany w poprzednim paragrafie problem niewspólmierności podmiotów poznawczych? Wydaje się, że nie. Wróćmy do poprzedniego przykładu, w którym uniwersalista poznawczy po prostu postanawia wierzyć, że nie-p. Cały czas jego postanowienie nie jest dla niego racją przemyślaną za nie-p, gdyż nie opiera się ono na jego zaufaniu we własne zdolności poznawcze. Decydując się, żeby wierzyć, że nie-p, w ogóle ich nie użył. Jest to sytuacja inna od tej, w której uniwersalista poznawczy zdecydowałby się wierzyć, że nie-p, rozważając wszelkie dostępne mu argumenty. Wtedy jego decyzja, by wierzyć, że nie-p, byłaby dodatkową racją przemyślaną za nie-p; racją, która wynikałaby z zaufania we własne zdolności poznawcze, niezależnie od tego, czy to zaufanie jest czymś pierwotnym, czy tė̇ budowało się przez lata ćwiczeń. Z drugiej strony, jeśli przypadkowo spotkana przez uniwersalistę poznawczego osoba głosi, że p, to powinien on zgodnie ze swym stanowiskiem uznać ten fakt za prima facie rację przemyślaną za p. Racja ta, wg Trinkaus Zagzebski, opiera się na zaufaniu, że jeśli uniwersalista poznawczy stara się dążyć do formułowania sądów prawdziwych, to ma on powody (na podstawie głoszonej przez siebie równości podmiotów poznających), by sądzić, że przypadkowo spotkana osoba również stara się do tego dążyć. Traktuje on z założenia wszystkie osoby jako wiarygodne w kwestii dążenia do prawdy, nawet jeśli nie ma on żadnych świadectw na rzecz ich wiarygodności ${ }^{17}$. W efekcie uniwersalista poznawczy

17 „If I believe that I am generally trustworthy and I accept the principle that I should treat cases alike, I am rationally committed to thinking that they are generally trustworthy 
w omawianym przykładzie dysponowałby racją przemyślaną za $\mathrm{p}$ i powinien, wbrew naszym intuicjom, przychylić się do zmiany sądu. Moim więc zdaniem, mimo wysiłków Trinkaus Zagzebski, kwestia niewspółmierności podmiotów poznawczych cały czas w jej teorii występuje.

Trinkaus Zagzebski proponuje jeszcze inne rozwiązanie, które rzeczywiście rozwiązuje kwestię niewspółmierności podmiotów (choć nie czyni ona tego w związku z tym problemem; jej zdaniem, podział na racje teoretyczne i przemyślane radzi sobie $z$ nim wystarczająco). Wprowadza ona mianowicie zasadę poznawczego zaufania innym (Principle of Epistemic Trust in Others), która mówi, że za każdym razem, gdy stwierdzam, że inni charakteryzują się sumiennością poznawczą, a więc cechą, która, gdy ją posiadam, sprawia, że ufam sobie, to mam prima facie rację, by ufać innym ${ }^{18}$.

Zastanówmy się, z jakim kosztem wiąże się to rozwiązanie? Fakt, że osoba $\mathrm{x}$ głosi, że p, jest, według uniwersalizmu poznawczego, prima facie racją za $\mathrm{p}$, ale jest to racja przemyślana. Taką racją jest np. moje zaufanie, że x jest ekspertem w danej dziedzinie. Co jednak decyduje, że obdarzam zaufaniem x-a? Zagzebski przyznaje, że jest to kwestia rozpoznania w kimś sumienności, a więc takich cnót intelektualnych, jak szczerość, rozwaga, zdolność ważenia racji, skrupulatność czy też obiektywizm. Rozpoznanie to może być nierefleksyjne: jest tak wtedy, gdy np. druga osoba budzi mój podziw, ale wtedy wymagane jest zaufanie w adekwatność swych uczuć $\mathrm{w}$ tym przypadku uczucia podziwu. To ono jest wtedy podstawą racjonalności przejmowania opinii od autorytetu ${ }^{19}$. W pewien sposób

also. I should regard them as generally trustworthy in advance of evidence of their trustworthiness just as I think of myself as trustworthy in advance of the evidence". Tenże, Epistemic Self-Trust and the Consensus Gentium Argument, art. cyt., 29.

18 Tenże, Epistemic Authority, dz. cyt., 68.

19 „Trust in my emotion of epistemic admiration gives me a prima facie reason to trust the desire to epistemically imitate another person by believing what she believes". Tamże, 90-91. 
ratuje to paradoks stanowiska uniwersalizmu poznawczego, związany z niewspółmiernością poznawczą podmiotów. Amerykańska filozofka mogłaby bowiem odrzec, że paradoksalność jej pozycji zniknie, kiedy uprzytomnimy sobie, że na gruncie zasady poznawczego zaufania innym mogę uznać to, co głosi dana osoba za rację za p tylko wtedy, gdy ufam, że sumiennie dąży ona do prawdy i że w swych wypowiedziach wyraża owo dążenie. Gdy to moje zaufanie ma podstawy (zbudowane albo na racji przemyślanej, którą jest uczucie podziwu wobec cnót intelektualnych danej osoby, albo na racjach teoretycznych, np. wiedzy o tytułach naukowych danej osoby lub o tym, że dana osoba znajduje się w lepszej lokalizacji czasoprzestrzennej, by coś spostrzec, itd.), to rzeczywiście lepiej jest ufać jej, niż własnym arbitralnym decyzjom. Trinakus Zagzebski może więc sobie wyobrazić uniwersalistę poznawczego, który nie traktuje wypowiedzi przypadkowo napotkanej przez siebie osoby, że p jako prima facie racji za p, gdyż taka osoba nie spełnia zasady poznawczego zaufania innym.

$Z$ drugiej jednak strony, taka odpowiedź zakłada, że to ja jestem tym, który rozpoznaje cechę sumienności. Zaufanie wobec innych przestaje być w Epistemic Authority czymś pierwotnym, ale opiera się na sądzie o wiarygodności przekonań wygłaszanych przez inne osoby, który to sąd wydałem w oparciu o swoje własne zdolności poznawcze. W ten sposób jednak poglądy Trinkaus Zagzebski zdają się niewiele różnić od stanowiska poznawczego egoizmu. Przecież Elisabeth Fricker (wobec której Trinkaus Zagzebski ustawia się w opozycji) równie ż uważa, że korzystanie z wiedzy eksperckiej jest racjonalne oraz zaleca, by ufać poznawczo innym tylko wtedy, gdy ma się ku temu dobre powody. Nadto twierdzi, że powyższe rady zgodne są $\mathrm{z}$ realizowaniem w swoim życiu ideału autonomii ${ }^{20}$. To, że Trinkaus Zagzebski de facto nie oddaliła się od stanowiska

20 „By trusting only cannily, and with good grounds, we can do much to retain epistemic self-governance". E. Fricker, dz. cyt., 239-240. 
egoizmu poznawczego, najlepiej widać we fragmencie, w którym rozważa ona następującą sytuację. Wyobraźmy sobie, że uważam (po własnej, sumiennej refleksji), że p. Osoba, którą uważam za autorytet epistemiczny, głosi, że nie-p. Co w takiej sytuacji radzi czynić Trinkaus Zagzebski? Zaufać swojej własnej refleksji. Koniec końców, i tak jestem więc zdany na siebie w poszukiwaniu prawdy (według niej, ja jestem dla siebie największym autorytetem) ${ }^{21}$. Samo przejmowanie poglądów od innych (nawet uchodzących za ekspertów w danej dziedzinie wiedzy) bez rozważenia, jakie mam podstawy, by sądzić, że ktoś jest autorytetem oraz bez zrozumienia jego racji jako racji, byłoby, jej zdaniem, irracjonalne. W ten sposób Trinkaus Zagzebski opowiada się ostatecznie za ideałem autonomii, którego głównym kryterium staje się już nie poleganie na własnych zdolnościach poznawczych, lecz zdolność do sumiennej autorefleksji ${ }^{22}$. Tym samym autorka ta akceptuje, mniej lub bardziej milcząco, poglądy, które stoją za stanowiskiem egoizmu poznawczego.

\section{UMIARKOWANY I SKRAJNY EGOIZM POZNAWCZY}

Nie chciałbym jednak czynić z ostatniej uwagi zarzutu. Mimo iż, według mnie, ostatecznie Trinkaus Zagzebski plasuje się w szeroko pojętym nurcie egoizmu poznawczego, to jej teoria, podkreślająca rolę autorytetu epistemicznego w dochodzeniu do prawdy, różni się od teorii, która kładzie nacisk wyłącznie na swoje własne zdolności poznawcze. Nawet jeśli ocenimy, że Trinkaus Zagzebski nie udało się obalić egoizmu poznawczego, to niewątpliwie skutecznie skrytykowała ona jego skrajną formę, zgodnie z którą fakt, że osoba x głosi, że p, nie jest nigdy jakąkolwiek racją za p. Filozofka ta słusznie zwróciła uwagę na to, że możemy dojść do przekonania

\footnotetext{
21 "I am proceeding from the assumption that the ultimate authority over oneself is oneself”. L. Trinkaus Zagzebski, Epistemic Authority, dz. cyt., 136.
}

22 Tamże, 236-237. 
o wiarygodności innych podmiotów poznawczych, a nawet czasem do przekonania, że inne podmioty są bardziej sumienne poznawczo ode mnie (wtedy stają się one dla mnie autorytetami poznawczymi). Racjonalnym jest wtedy uznać, że fakt, iż autorytet epistemiczny twierdzi, że p, jest już prima facie racją za $\mathrm{p}^{23}$. Ten punkt widzenia nie utożsamia się z uniwersalizmem poznawczym, gdyż odrzuca tezę, że zaufanie poznawcze innym jest uprzednie wobec jakiejkolwiek refleksji (innymi słowy odrzuca tezę, że zawsze fakt głoszenia przez osobę x poglądu, że p jest prima facie racją za p), jednak z powodu wskazanych wcześniej w artykule niechcianych konsekwencji uniwersalizmu poznawczego, nie wydaje się to być wadą teorii Trinkaus Zagzebski. Wobec powyższych uwag nazwałbym jej stanowisko umiarkowanym egoizmem poznawczym.

Główna różnica między skrajnym a umiarkowanym egoizmem poznawczym polegałaby na tym, że ten drugi dopuszczałby racje przemyślane do zbioru racji, jakimi może dysponować podmiot, uzasadniając swoje przekonania. Skrajny egoista, uznając tylko racje teoretyczne przemawiające za uznaniem wiarygodności poznawczej innego (Fricker wymienia tu takie racje jak (1) fakt, że ktoś jest w lepszym położeniu, by coś osądzić, (2) fakt, że ktoś posiada pod jakimś względem lepsze zdolności poznawcze ode mnie, np. lepszy wzrok i (3) fakt, że ktoś jest lepiej wyspecjalizowany w danej dziedzinie wiedzy) ${ }^{24}$, nie może uznać za uzasadnionego twierdzenia, które opiera się tylko na zaufaniu w adekwatność emocji podziwu, którym obdarza się autorytet epistemiczny. Dlatego też skrajny egoizm poznawczy jest wrażliwy na zarzut postawiony w 2. paragrafie artykułu, a mianowicie, że konsekwencją tego stanowiska jest to, że nie mogę o sobie powiedzieć, że wiem o rzeczach, o których wiedzę czerpię wyłącznie z drugiej ręki. Jako przykład podałem tezę o tym, że konsekwencją ogólnej teorii względności jest dynamiczna przestrzeń

23 Tamże, 104-105.

24 E. Fricker, dz. cyt., 234-235. 
fizyczna (nazwijmy ją tezą A). Egoista skrajny może powiedzieć, że wie, że A tylko wtedy, gdy potrafi uzasadnić A samodzielnie lub gdy samodzielnie rozpoznał, że osoba x jest ekspertem w danej dziedzinie. Tymczasem jeśli komuś brak wiedzy matematycznej i fizycznej do tego, by sprawdzić, jakie są konsekwencje ogólnej teorii względności, to ta sama ignorancja nie pozwoli mu samodzielnie sprawdzić, czy $\mathrm{x}$ jest ekspertem w danej dziedzinie. Natomiast w tej samej sytuacji egoista umiarkowany może twierdzić, że wie, że A, mimo że nie potrafi samodzielnie uzasadnić $A$, gdyż jako racjonalne uzasadnienie A przyjmuje on odwołanie się do swego uczucia podziwu wobec cnót intelektualnych osób, takich jak Hawking czy Heller, które twierdzą, że A.

\section{PODSUMOWANIE}

Analizy Trinkaus Zagzebski na temat autorytetu poznawczego i jego domniemanej sprzeczności z ideałem autonomii prowadzą do refleksji na dwa kluczowe tematy współczesnej filozofii:

1. Na czym polega racjonalność człowieka? Trinkaus Zagzebski sprzeciwia się poglądowi, zgodnie z którym kryterium racjonalności jest całkowita samodzielność w formułowaniu swych przekonań. Według niej, prawdziwym kryterium tego, czy dana osoba jest racjonalna, jest zdolność do formułowania sądów prawdziwych (czy też łagodząc wyżej wskazane kryterium zdolności do formułowania sądów, zdolnych przetrwać sumienną autorefleksję). Ponieważ do tego, by głosić sądy prawdziwe, przydatne jest korzystanie z pomocy autorytetów epistemicznych, to Trinkaus Zagzebski przekonująco argumentuje, że zaufanie autorytetom nie tyle nie jest sprzeczne z ludzką racjonalnością, co jest nawet jej wymogiem.

2. Natura podmiotu poznającego. W swych rozważaniach dotknęliśmy kwestii niewspółmierności podmiotów poznających. Wiąże się ona z pytaniem, czy zaufanie w poznawcze zdolności 
innych ludzi jest czymś pierwotnym, czy też opartym na sądzie o ich wiarygodności? Jeśli owo zaufanie byłoby czymś pierwotnym, to wtedy inne osoby byłyby w pewien sposób uprzywilejowane $\mathrm{w}$ stosunku do mnie, jeśli chodzi o kompetencje poznawcze. Ich sąd, że p, byłby bowiem dla mnie prima facie racją za p. W przeciwieństwie do tego, fakt, że ja głoszę, że p, nie byłby dla mnie żadną dodatkową racją wzmacniającą tezę, że p. Jeśli, z drugiej strony, zaufanie w zdolności poznawcze innych ludzi jest oparte o sąd o ich wiarygodności, niezależnie od tego, czy sąd ten uzasadniam racjami teoretycznymi czy przemyślanymi, to z kolei ja zajmuję uprzywilejowaną pozycję w stosunku do innych ludzi, jeśli chodzi o kompetencje poznawcze. Zaufanie do ich zdolności poznawczych wymagałoby bowiem uzasadnienia, zaś zaufanie we własne zdolności poznawcze (pod groźbą regressum ad infinitum) byłoby czymś pierwotnym ${ }^{25}$.

Podsumowując, dyskusja nad autorytetem epistemicznym stawia nas wobec alternatywy: albo uniwersalizm poznawczy, którego ceną jest akceptacja niewspółmierności podmiotu poznającego względem innych podmiotów, albo egoizm poznawczy, którego konsekwencją jest to, że nie można twierdzić, że fakt, że osoba x głosi, że p, jest prima facie racją za p. Jak powiedziałem wcześniej, Trinkaus Zagzebski opowiada się za tym drugim rozwiązaniem (choć, moim zdaniem, błędnie klasyfikuje je jako stanowisko uniwersalizmu poznawczego). Ciekawym zadaniem byłaby próba rozwinięcia pierwszego rozwiązania. Być może pomogłyby w tym prace autorów, którzy skądinąd głosili niewspółmierność ja względem innych podmiotów (choćby jak

25 Jeśli zaufanie do własnych zdolności poznawczych nie byłoby pierwotne, to wymagałoby jakiegoś uzasadnienia, np. sądu B. Wtedy zaś pojawiłaby się kwestia, na jakiej zasadzie ufam w prawdziwość B. Jeśli znów dysponowałbym jakimś sądem (np. sądem C) uzasadniającym tę ufność, to nic nie stoi na przeszkodzie zapytać się znów o racje zaufania w prawdziwość sądu C, itd. Rozwiązaniem jest przyjęcie, że zaufanie w to, że moja percepcja czy intelekt działają poprawnie, jest czymś pierwotnym. 
czynił to Emmanuel Lévinas na gruncie etyki), ale jest to kwestia, której nie sposób rozważyć w tym artykule.

\section{BIBLIOGRAFIA}

Alston W. P., Beyond Justification: Dimensions of Epistemic Evaluation, Cornell University Press, Ithaca 2005.

Blaauw M., Pritchard D., Epistemology A-Z, Palgrave Macmilian, New York 2005. Bocheński J. I. M., Logika religii, tłum. z ang. S. Magala, Instytut Wydawniczy Pax, Warszawa 1990.

Chisholm R. M., Teoria poznania, tłum. R. Ziemińska, Daimonion, Lublin 1994. Cook J., Nuticelli D., Quantifying the Consensus on Anthropogenic Global Warming in the Scientific Literature, Environmental Research Letters, 8(2013)2, doi: 10.1088/1748-9326/8/2/024024.

Foley R., Intellectual Trust in Oneself And Others, Cambridge University Press, Cambridge 2001.

Fricker E., Testimony and Epistemic Autonomy, w: The Epistemology of Testimony, red. J. Lakey, R. Sosa, Clarendon Press, Oxford 2006, 225-250.

Locke J., List o tolerancji, tłum. $\mathrm{z}$ ang. L. Joachimowicz, Państwowe Wydawnictwo Naukowe, Warszawa 1963.

Trinkaus Zagzebski L., Epistemic Self-Trust and the Consensus Gentium Argument, w: Evidence and Religious Belief, red. K. J. Clark, R. J. Vanarragon, Oxford University Press, Oxford 2011, 22-36.

Trinkaus Zagzebski L., Epistemic Authority. A Theory of Trust, Authority and Autonomy in Belief, Oxford University Press, Oxford 2012.

\section{LINDA TRINKAUS ZAGZEBSKI'S THEORY OF EPISTEMIC AUTHORITY: ABOUT THE NEED FOR TRUST IN OTHERS}

\footnotetext{
Abstract. In this paper the author analyzes Trinkaus Zagzebski's theory of epistemic authority. This theory underlines the importance of trust in the process of justification of beliefs and it indicates the limitations of so called epistemic egoism. The ideal for epistemic egoism is self-reliance of a subject in justifying his or her beliefs. Trinkaus Zagzebski defends so called epistemic universalism, according to which, the mere fact that a person $x$ claims that $p$ is a prima facie reason in favor of $p$. In the text the author indicates the weak points of universalism and concludes that either one accepts this point of view with its consequence rejecting the thesis of equality of epistemic subjects or one adheres to the
} 
point of view of epistemic egoism. The author claims that Trinkaus Zagzebski gives a reader indications how to improve this standpoint so it does not result in counterintuitive claims.

Keywords: epistemic authority, epistemic egoism, epistemic universalism, epistemic trust in others, epistemic foundationalism, theoretical and deliberative reasons, epistemic conscientiousness

\author{
MAREK DOBRZENIECKI \\ mdobrzeniecki@pwtw.pl \\ Papieski Wydział Teologiczny w Warszawie, Collegium Joanneum \\ Dewajtis 3, 01-815 Warszawa
}

DOI: 10.21697/spch.2016.52.2.02

Artykuł powstał w ramach projektu badawczego NCN „Epistemologia doświadczenia religijnego w myśli rosyjskiej i żydowskiej” (2014/13/B/HS1/00761). 